\title{
Penggunaan Media Youtube dalam Meningkatkan Hasil Belajar Materi Zakat dan Hikmahnya di Madrasah Aliyah Miftahul Ulum
}

\author{
Imam Subqi \\ Institut Agama Islam Negeri Salatiga, Indonesia \\ *Corresponding Author. Email: imamsubqi@iainsalatiga.ac.id
}

\begin{abstract}
This study aims to determine the activeness and learning outcomes of students on zakat material and its wisdom through youtube media at Madrasah Aliyah Miftahul Ulum Weding Demak. The research used is a classroom action research approach. The results showed that based on the results of the last recap, it appears that the learning outcomes from cycle I to cycle III have increased. In the first cycle the average results obtained were 66.36 , increasing to 73.60 or $7.24 \%$ in the second cycle. In the third cycle the average value reached 76.78 , an increase from the second cycle of $3.18 \%$. From these data, it can be concluded that with the optimal application of youtube media in fiqh learning for class X Miftahul Ulum Weding Demak students can improve learning outcomes.
\end{abstract}

\begin{abstract}
Abstrak: Penelitian ini bertujuan untuk mengetahui keaktifan dan hasil belajar siswa materi zakat dan hikmahnya melalui media youtube di Madrasah Aliyah Miftahul Ulum Weding Demak. Penelitian yang digunakan dngan pendekatan penelitian tindakan kelas. Hasil penelitian menunjukan bahwa berdasarkan hasil rekap terakhir tampak bahwa hasil belajar dari siklus I sampai dengan siklus III mengalami peningkatan. Pada siklus I hasil rata-rata yang diperoleh adalah 66,36 meningkat menjadi 73,60 atau 7,24\% pada siklus II. Pada siklus III nilai rata-rata mencapai 76,78 meningkat dari siklus II sebesar 3,18\%. Dari data tersebut dapat ditarik kesimpulan bahwa dengan penerapan media youtube secara optimal pada pembelajaran fikih siswa kelas X Miftahul Ulum Weding Demak dapat meningkatkan hasil belajar
\end{abstract}

\section{Article History}

Received: 15-07-2021

Reviewed: 11-08-2021

Accepted: 26-09-2021

Published: 18-10-2021

\section{Key Words}

Media, Youtube,

Learning Outcomes.

\section{Sejarah Artikel}

Diterima: 15-07-2021

Direview: 11-08-2021

Disetujui: 26-09-2021

Diterbitkan: 18-10-2021

\section{Kata Kunci}

Media, Youtube, Hasil

Belajar.

How to Cite: Subqi, I. (2021). Penggunaan Media Youtube dalam Meningkatkan Hasil Belajar Materi Zakat dan Hikmahnya di Madrasah Aliyah Miftahul Ulum Weding Demak. Jurnal Teknologi Pendidikan : Jurnal Penelitian dan Pengembangan Pembelajaran, 6(2), 142-151. doi:https://doi.org/10.33394/jtp.v6i2.3246

https://doi.org/10.33394/jtp.v6i2.3246

This is an open-access article under the CC-BY-SA License.

\section{Pendahuluan}

Indonesia sejak pandemi covid-19 pada tahun 2020 telah merubah semua sektor kehidupan, sosial, ekonomi, budaya dan bahkan proses pembelajaran di sekolah. Dalam ranka meminamalisir dan mengurangi penularan covid-19 pemerintah membuat kebijakan dengan No 36926/MPKA/HK/2020 tentang pembelajaran daring bagi sekolah dengan proses pembelajaran yang menyenangkan (Sari et al., 2020). Pandemi covid-19 telah mempengaruhi semua sektor kehidupan manusia, diantaranya adalah sektor pendidikan yang mengharuskan merubah model pembelajaran dari luring menjadi daring, sehingga semua yang terlibat dalam proses pembelajaran harus bersinergi untuk saling mengisi sehingga tercapainya tujuan pembelajaran (Wijayanto et al., 2020). Pembelajaran jarak jauh yang selama ini digunakan beberapa lembaga pendidikan telah menjadi acuan untuk pembelajaran masa depan yang 
mengedepankan kemudahan dengan memanfaatkan jaringan informasi-koneksi untuk belajaran jarak jauh sebagai alternatif untuk tetap melakukan proses pembelajaran.

Disisi lain pembelajaran harus tetap berjalan saat masih pandemi dengan berbagai kendala-kendala yang dialami dunia pendidikan selama ini, kendala klasik dalam proses pembelajaran masih berorientasi pada pembelajaran berpusat pada pendidik sehingga anak didik diminta dan diarahkan pada pembelajaran yang sifatnya menghafal teori-teori atau kemampuan menghafal dan berdampak langsung saat nantinya lulus sekolah belum siap secara matang karena akan hanya menguasai secara kognitif namun masih rendahnya praktek atau aplikasi, oleh karena itu pendidik harus mampu bisa mengantarkan anak didiknya mampu berfikir secara kritis sehingga mampu menguasai materi atau konsep secara sistematis baik teori maupun aplikatif (D Rahmawati S.E, Nugroho, 2014).

Mata pelajaran Fiqih sebagai salah satu pelajaran yang ada di Madrasah Aliyah bertujuan memberi bekal pada anak didik dalam ibadah secara benar dikemas dengan disiplin ilmu bernama ilmu fiqih. Dari proses tersebut kendala yang dihadapi oleh pendidik diantaranya masih rendahnya tercapian KKM yang telah ditentukan. Kendala berikutnya adalah masa pandemi itu sendiri dengan kebijakan pemerintah pusat terkait dengan proses pembelajaran harus menggunakan model daring yang proses pembelajaran sebelumnya dengan luring menjadi daring, ini secara psikologi berdampak dengan gaya belajar. Sedangkan pendidikan sendiri harus tetap di jalankan dengan berbagai keterbatasan yang dimiliki oleh lembaga pendidikan.

Belum maksimalnya proses pembelajaran selama ini dengan dibuktikan bahwa nilai masih banyak dibawah rata-rata atau di bawah KKM karena beberapa pendidik masih banyak yang menggunakan beberapa metode pembelajaran model klasik yaitu ceramah menjadikan anak didik kurang senang dan maksimal (Sunardi, 2021). Oleh karena itu pembelajaran yang menyenangkan belum sepenuhnya diterapkan di Madrasah Aliyah, para pendidik yang masih belum mau melakukan perubahan adalah kendala untuk pencapaian KKM. Sedangkan materi pelajaran Fikih pada dasarnya akan memberikan bekal pada anak didik cara beribadah secara menyeluruh dan benar agar lulusan yang diciptakan menjadi insan-insan yang bertaqwa.

Beberapa kendala lain yang ditemukan di sekolah adalah masih sedikitnya pendidik yang bisa memanfaatkan media pembelajaran seperti video, gambar atau lainnya dan juga masih sedikitnya media yang telah disediakan oleh sekolah-sekolah (laboratorium), (Rasimin et al., 2012) sedangkan media sangat dibutuhkan untuk memudahkan proses pembelajaran dan seharusnya pendidik harus mampu melakukan inovasi pembuatan media khususnya di saat pandemi pendidik dituntut untuk bisa memanfaatkan segala sesuatu untuk kepentingan proses pembelajaran dan tercapainya tujuan pembelajaran dengan berbagai media yang masih sederhana (Elianur, 2020).

Beberapa penelitian yang relevan dengan penelitian ini adalah Susanti, E T dan Amelia, M dengan judul penelitiannya pemanfaatan youtube sebagai media pembelajaran matematika dimasa pandemi covid-19, hasil penelitian tersebut menjelaskan bahwa adanya peningkatan nilai kreativitas mahasiswa 2,45 menjadi 3,07 saat pertemuan kedua sebesar 
3,47. Sedangkan pada pertemuan ketiga rata-rata kreativitas mahasiswa sudah mencapai 3,00, dengan proses peningkatan tersebut menunjukan bahwa pemanfaatan media youtube mampu mengembangkan kreativitas mahasiswa khususnya sikap merasa tertarik (Susanti \& Amelia, 2021). Achmad Baihaqi, dengan judul penelitiannya Youtube sebagai Media Pembelajaran Pendidikan Agama Islam Efektif di SMK Nurul Yaqin Sampang, hasil penelitian yang didapatkan adalah proses pembelajaran pendidikan Agama Islam lebih efektif dan mudah khususnya dalam pencarian informasi atau pemindahan informasi serta meningkatnya profesionalitas pendidik dalam penggunaan media youtube sehingga anak didik lebih tertarik untuk melakukan proses pembelajaran khususnya di SMK Nurul Yaqin Sampang (Baihaqi et al., 2020). Penelitian Carlos Orús, María José Barlés, Daniel Belanche, Luis Casaló dengan judul The effects of learner-generated videos for YouTube on learning outcomes and satisfaction, hasil penelitian tersebut menunjukan bahwa partisipasi aktif memiliki pengaruh langsung pada perolehan kompetensi lintas kurikuler yang dirasakan dan kinerja akademik. Sementara partisipasi tidak secara langsung meningkatkan pembelajaran subjektif atau kepuasan dengan kursus, itu memiliki pengaruh tidak langsung melalui kompetensi lintas kurikuler (Carlos Orús, María José Barlés, Daniel Belanche, 2016). Dari beberapa penelitian yang relevan di atas jelas berbeda dengan penelitian ini yaitu lebih fokus pada bagaimana penerapan media youtube dalam meningkatkan keaktifan dan hasil belajar siswa materi zakat dan hikmahnya melalui media youtube di Madrasah Aliyah Miftahul Ulum Weding Demak.

\section{Metode Penelitian}

Penelitian ini menggunakan penelitian tindakan kelas dengan asumsi mampu menyelesaikan persoalan pembelajaran di kelas. Penelitian tindakan kelas merupakan suatu cermatan atau tindakan yang dilakukan oleg seorang pendidik di kelas untuk menyelesaikan persoalan pembelajaran di kelas (Jacub et al., 2019). Penelitian tindakan kelas dilakukan dengan beberapa siklus dalam rangka menuntaskan permasalahan belajar sehingga ditandai dengan perubahan serta peningkatan hasil belajar bagi anak didik (Nurgiansah et al., 2021). Penggunaan media youtube dalam pembelajaran jarak jauh akan mampu meningkatkan hasil belajar.

Penelitian ini akan melakukan kolaborasi antara peneliti dengan pendidik yang melaksanakan PTK secara langsung. Dalam hal penelitian tindakan kelas bertujuan untuk menyelesaikan persoalan pembelajaran yang ada di kelas, dengan mengacu pendapatnya Kemmis mengungkapkan bahwa PTK berbentuk spiral yang tahapannya berbentuk siklus dengan diawali sebuah perencanaan, pelaksanaan, refleksi dan evaluasi dengan diawali sebuah observasi untuk melihat kondisi anak didik sebelum dilakukan penelitian tindakan kelas/ Penelitian ini dilaksanakan pada semester pertama dengan pertimbangan kalender akademik yang ada di sekolah yaitu bulan september 2021. Lokasi penelitian ini mengambil tempat pada siswa Kelas X Madrasah Aliyah Miftahul Ulum Weding Demak. Penelitian ini fokus pada mata pelajaran Fiqih tentang zakat dan hikmahnya. 
Penelitian tindakan kelas ini dilaksanakan dengan tiga siklus untuk melihat peningkatan hasil belajar zakat dan hikmahnya pada siswa Kelas X Madrasah Aliyah Miftahul Ulum Weding Demak. Subjek penelitian adalah siswa kelas X yang terdiri dari 28 siswa terdiri dari 15 siswa laki-laki dan 13 siswa perempuan. Sebelum PTK dilaksanakan dibuat berbagai input instrumental yang akan digunakan untuk memberi perlakuan dalam PTK, yaitu rencana pembelajaran yang akan dijadikan PTK, yaitu kompetensi dasar yang di dalamnya memuat pembelajaran zakat dan hikmahnya yang terdapat pada silabus pembelajaran kelas $\mathrm{X}$ mata pelajaran Fikih. Selain itu juga akan dibuat perangkat pembelajaran yang berupa: (1) Lembar kerja siswa, (2) Lembar pengamatan diskusi, (3) Lembar evaluasi. Sementara beberapa sumber data dari penelitian ini yaitu siswa, pendidik dan kolaborator.

Teknik pengumpulan data dalam penelitian ini adalah observasi, angket, wawancara dan diskusi. Observasi merupakan metode pengamatan dan pencatatan dengan sistematis terhadap fenomena-fenomena yang diselidiki (Salim, 2015). Angket adalah daftar yang berisi suatu rangkaian pertanyaan mengenai suatu hal atau dalam suatu bidang untuk memperoleh data berupa jawaban dari responden (Arikunto, 2017). Adapun wawancara di sini penulis gunakan untuk mendapatkan data primer dan skunder. Tes menggunakan lembar zakat dan hikmahnya untuk mengukur kemampuan menjelaskan ketentuan Islam tentang zakat dan hikmahnya dan mengidentikasi undang-undang pengelolaan zakat. Observasi menggunakan lembar observasi untuk mengukur tingkat kemampuan siswa dalam menjelaskan ketentuan Islam tentang zakat dan hikmahnya dan mengidentikasi undang-undang pengelolaan zakat dalam proses belajar mengajar zakat dan hikmahnya pada mata pelajaran Fikih. Wawancara menggunakan panduan wawancara untuk mengetahui pendapat atau sikap siswa dan teman sejawat tentang pembelajaran dengan menggunakan media youtube dalam daring. Kuesioner untuk mengetahui pendapat atau sikap siswa dan kolaborator tentang pembelajaran dengan menggunakan media youtube dalam pembelajaran jarak jauh. Lembar penugasan berupa perubahan tingkat pemahaman.

Data yang dikumpulkan pada setiap kegiatan observasi dari pelaksanaan siklus penelitian dianalisis secara deskriptif dengan menggunakan teknik persentase untuk melihat kecenderungan yang terjadi dalam kegiatan pembelajaran. Kualitas kemampuan menjelaskan ketentuan Islam tentang zakat dan hikmahnya dan mengidentikasi undang-undang pengelolaan zakat, dengan menganalisis nilai rata-rata tugas yang diberikan. Kemudian dikategorikan dalam klasifikasi tinggi, sedang, dan rendah. Implementasi pembelajaran menggunakan media youtube dalam pembelajaran daring dengan menganalisis tingkat keberhasilan implementasi, kemudian dikategorikan dalam klasifikasi berhasil, kurang berhasil dan tidak berhasil. 


\section{Prosedur Penelitian}

\section{Siklus I}

Siklus pertama dalam PTK ini terdiri dari perencanaan, pelaksanaan, pengamatan dan refleksi sebagai berikut: (a) Perencanaan (Planning) yang terdiri dari peneliti dan kolaborator melakukan analisis kurikulum untuk mengetahui kompetensi dasar yang akan disampaikan kepada siswa pada pembelajaran dengan menggunakan media youtube dalam pembelajaran daring, membuat rencana pembelajaran dengan media youtube dalam pembelajaran daring. Membuat lembar kerja siswa dan pekerjaan rumah yaitu mengidetifikasi zakat dan hikmahnya.

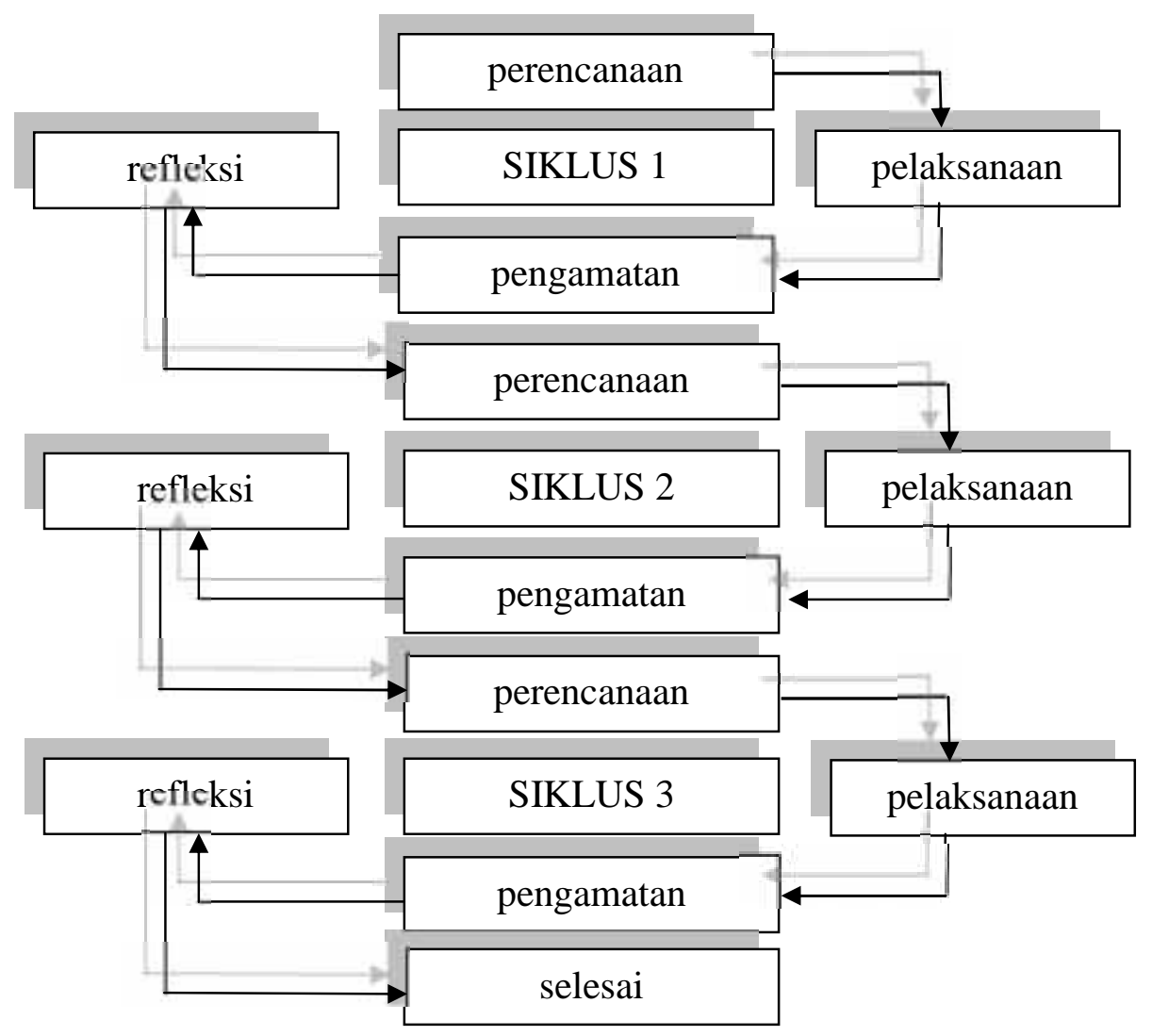

Gambar 1. Siklus Penelitian Tindakan Kelas (Arikunto, 2017)

Membuat instrumen yang digunakan dalam siklus PTK dan menyusun alat evaluasi pembelajaran. (b) Pelaksanaan (Acting) yang terdiri dari membagi lembar urutan tugas yang harus dikuasai siswa. Menyajikan materi pelajaran dan diberikan tugas. Dalam setiap tugas, dilakukan secara individual dan kelompok. Salah satu siswa yang sedang mengerjakan tugas materi zakat dan hikmahnya, dan jelas agar siswa yang lain ikut serta mengoreksi. Pendidik memberikan kuis atau pertanyaan. Siswa diberikan kesempatan untuk memberikan tanggapan. Penguatan dan kesimpulan secara bersama-sama serta melakukan pengamatan atau observasi. (c) Pengamatan (Observation) dengan situasi kegiatan belajar mengajar dan keaktifan siswa, serta siswa dalam penguasaan kemampuan menjelaskan ketentuan Islam 
tentang zakat dan hikmahnya dan mengidentikasi undang-undang pengelolaan zakat. (d) Refleksi (Reflecting), penelitian tindakan kelas ini berhasil apabila memenuhi beberapa syarat sebagai berikut pertama, dari 28 siswa berani dan mampu menjelaskan ketentuan Islam tentang zakat dan hikmahnya dan mengidentikasi undang-undang pengelolaan zakat yang diberikan dengan alat ukur instrumen yang telah disediakan dan penyelesaian tugas sesuai dengan waktu yang disediakan.

\section{Siklus II}

Seperti halnya siklus pertama, siklus kedua pun terdiri dari perencanaan, pelaksanaan, pengamatan, dan refleksi. (a) Perencanaan (Planning) (b) Pelaksanaan (Acting), (c) Pengamatan (Observation), (d) Refleksi (Reflecting)

\section{Siklus III}

Siklus III merupakan putaran ketiga dari pembelajaran dengan menggunakan media youtube dalam pembelajaran daring dengan tahapan yang sama seperti pada siklus I dan II yaitu (a) Perencanaan (Planning), (b) Pelaksanaan (Acting) (c) Pengamatan (Observating), (d) Reflektif (Reflecting)

\section{Hasil dan Pembahasan \\ Deskripsi Kondisi Awal}

Penguasaan materi fikih siswa kelas X Madrasah Aliyah Miftahul Ulum Weding Demak tahun 2021 belum semuanya dapat dikatakan tuntas. Hal ini dapat diketahui dari hasil tes awal sebelum dilaksanakan tindakan kelas yaitu dengan penerapan media youtube. Adapun hasil tes awal dapat dilihat siswa yang tuntas hanya 15 siswa atau 51,16\% sedangkan yang belum tuntas sebanyak 13 siswa atau $48,84 \%$.

Tabel 1. Rata-rata Hasil Tes Awal

\begin{tabular}{lllccc}
\hline No & Rentang Nilai & Kategori & Frekuensi & Prosentase & Rata-rata Kelas \\
\hline $85-100$ & Sangat Baik & 0 & 0 & \\
$70-84$ & Baik & 8 & 28,57 & 61,25 \\
$55-69$ & Cukup & 18 & 64,28 & \\
$40-54$ & Kurang & 2 & 7,14 & \\
& & 28 & $100 \%$ & \\
\hline
\end{tabular}

Berdasarkan tabel di atas menunjukkan bahwa hasil belajar siswa kelas X Madrasah Aliyah Miftahul Ulum Weding Demak pada standar kompetensi menjelaskan ketentuan Islam tentang zakat dan hikmahnya dan mengidentikasi undang-undang pengelolaan zakat sebelum diadakan tindakan kelas mencapai rata-rata kelas 61,25 dalam kategori cukup dengan rincian sebagai berikut; dari nilai 85-100 tidak ada satu pun siswa yang mendapat nilai tersebut, siswa yang mendapat nilai baik dengan rentang 70-84 sebanyak 8 siswa atau sekitar 28,57\%, siswa yang memperoleh nilai cukup dengan rentang nilai 55-69 sebanyak 18 siswa atau $64,28 \%$. Siswa yang mendapat nilai kurang dengan rentang nilai 40-54 sebanyak 2 siswa atau $7,14 \%$. Nilai rata-rata kelas sebanyak 61,25 yang artinya nilai rata-rata tersebut masih di bawah nilai KKM mata pelajaran fikih yakni 70 dengan kondisi awal tersebut maka perlu diadakan tindakan. Dalam mengetahui bagaimana penerapan media youtube yang dilakukan 
pendidik digunakan lembar penilaian berdasarkan lembar observasi atau pengamatan. Adapun hasilnya menunjukkan bahwa rata-rata prosentase penilaian total dari hasil pengamatan terhadap penerapan media youtube pada siklus I mencapai rata-rata $62,5 \%$ dengan kategori cukup.

Sedangkan untuk mengetahui dampak penerapan media youtube, pada akhir proses pembelajaran, siswa diberi tes formatif I dengan tujuan untuk mengetahui tingkat keberhasilan siswa dalam proses pembelajaran yang telah dilakukan. Adapun hasil test siklus I dilihat siswa yang tuntas hanya 20 siswa atau $71,43 \%$ sedangkan yang belum tuntas sebanyak 8 siswa atau $28,57 \%$.

Tabel 2. Rata-Rata Hasil Test Siklus I

\begin{tabular}{cccccc}
\hline No & Rentang Nilai & Kategori & Frekuensi & Prosentase & Rata-rata Kelas \\
\hline 1 & $85-100$ & Sangat Baik & 0 & 0 & \\
2 & $70-84$ & Baik & 15 & 53,57 & 66,36 \\
3 & $55-69$ & Cukup & 13 & 46,43 & \\
4 & $40-54$ & Kurang & 0 & 0 & \\
& & & 28 & $100 \%$ & \\
\hline
\end{tabular}

Berdasarkan tabel di atas menunjukkan bahwa hasil belajar siswa kelas X MA Miftahul Ulum Weding Demak pada siklus I setelah diterapkanya media youtube mencapai rata-rata kelas 66,36 dalam kategori cukup dengan rincian sebagai berikut; dari nilai 85-100, masih kosong, siswa yang memperoleh nilai baik 15 siswa atau 53,57\% dengan rentang nilai 70-84, yang mendapat nilai cukup 13 atau sebesar 46,43\% siswa dengan rentang nilai 55-69, siswa yang mendapat nilai kurang sudah tidak ada atau dengan rentang nilai 40-54. Dalam pembelajaran siklus I sudah sesuai dengan menggunakan media youtube, ini terlihat jelas pada rencana pelaksana pembelajaran (RPP) dan pelaksanaannya. Kegiatan pendidik dalam pembelajaran ini sudah baik, ada beberapa aspek yang belum mencapai $100 \%$ antara lain persiapan pendidik memulai pelajaran $50 \%$, kemampuan pendidik mengelola kelas $50 \%$, menyajikan pertanyaan atau permasalahan $50 \%$, membimbing membuat kesimpulan $50 \%$. Ini yang menjadi tindakan lebih lanjut pada siklus II agar lebih baik. Berdasarkan penilaian pelaksanaan media youtube dan metode pembelajaran yang mencapai niilai rata-rata hasil belajar siswa sebesar 66 maka diputuskan diadakan perbaikan pada siklus II.

\section{Deskripsi Hasil Siklus II}

Pada tahap penelitian, peneliti mempersiapkan perangkat pembelajaran yang terdiri dari pembelajaran II, soal tes formatif II dan alat-alat pembelajaran yang mendukung. Selaini tu juga dipersiapkan lembar observasi atau pengamatan. Sementara pada pelaksanaan Pendidik dengan mengacu pada rencana pelaksanaan pembelajaran, perencanaan siklus II dan hasil refleksi dari hasil siklus I kemudian dengan peserta didik berjumlah 28 orang, dengan tetap melakukan motivasi pada peserta didik serta bertanya terkait dengan kendala yang dihadapi dalam pembelajaran zakat dan hikmahnya pada siklus 1. Dalam mengetahui bagaimana penerapan media youtube yang dilakukan pendidik digunakan lembar penilaian berdasarkan lembar observasi atau pengamatan. Adapun hasilnya menunjukkan bahwa rata- 
rata prosentase penilaian total dari hasil pengamatan terhadap penerapan media youtube pada siklus II mencapai rata-rata $100 \%$ dengan kategori sangat baik. Sedangkan untuk mengetahui dampak penerapan media youtube, pada akhir proses pembelajaran, siswa diberi tes formatif II dengan tujuan untuk mengetahui tingkat keberhasilan siswa dalam proses pembelajaran yang telah dilakukan. Adapun hasil test siklus II dilihat siswa yang tuntas hanya 23 siswa atau $82,14 \%$ sedangkan yang belum tuntas sebanyak 5 siswa atau 17,86\%. Dari data di atas dapat dilihat siswa yang tuntas hanya 23 siswa atau 82,14\% sedangkan yang belum tuntas sebanyak 5 siswa atau $17,86 \%$. Selanjutnya dijabarkan rata-rata hasil test siklus II sebagai berikut:

Tabel 3. Rata-Rata Hasil Test Siklus II

\begin{tabular}{cccccc}
\hline No & Rentang Nilai & Kategori & Frekuensi & Prosentase & Rata-rata Kelas \\
\hline 1 & $85-100$ & Sangat Baik & 5 & 17,85 & \\
2 & $70-84$ & Baik & 19 & 67,86 & 73,60 \\
3 & $55-69$ & Cukup & 4 & 14,29 & \\
4 & $40-54$ & Kurang & - & - & \\
& & & 28 & $100 \%$ & \\
\hline
\end{tabular}

Berdasarkan tabel di atas menunjukkan bahwa hasil belajar siswa kelas X MA Miftahul Ulum Weding Demak pada siklus II setelah diterapkanya media youtube mencapai rata-rata kelas 73,60 dalam kategori baik dengan rincian sebagai berikut; dari nilai 85-100, 5 siswa atau sekitar 17,85 \%, siswa yang memperoleh nilai baik 19 siswa atau 67,86\% dengan rentang nilai 70-84, yang mendapat nilai cukup 4 atau sebesar $41,29 \%$ siswa dengan rentang nilai 55-69, siswa yang mendapat nilai kurang tidak ada.

Dalam pembelajaran siklus II sudah sesuai dengan langkah-langkah pembelajaran penggunaan media youtube, ini terlihat jelas pada Rencana Pelaksana Pembelajaran (RPP) dan pelaksanaannya. Kegiatan pendidik dalam pembelajaran ini sudah baik, semua aspek penilaian atau pengamatan pendidik dalam penerapan media youtube mencapai $100 \%$. Dan nilai belajar siswa mecapai rata-rata kelas sebesar 73,60. Berdasarkan penilaian pelaksanaan media youtube mencapai nilai rata-rata 100 dan rata-rata kelas hasil belajar siswa sebesar 73,60 berarti ketuntasan secara klasikal belum tercapai, untuk itu diputuskan diadakan perbaikan pada siklus III.

\section{Deskripsi Hasil Siklus III}

Pada tahap ini perencanaan, peneliti mempersiapkan perangkat pembelajaran yang terdiri dari pembelajaran III, soal tes formatif III dan alat-alat pembelajaran yang mendukung. Selain itu juga dipersiapkan lembar observasi atau pengamatan. Pelaksanaan kegiatan belajar mengajar untuk siklus III dilaksanakan dengan jumlah siswa 28 anak, dalam hal ini peneliti bertindak kolaborator pendidik. Adapun proses pembelajaran mengacu pada Rencana Pelaksanaan Pembelajaran (RPP) yang telah dipersiapkan dan hasil refleksi hasil siklus II serta perencanaan siklus III. Dari pelaksnaan siklus III ini hampir sama dengan yang dilakukan pada siklus II namun lebih memperhatikan lagi pada siswa yang belum tuntans di siklus II sebanyak 4 orang dengan nilai masih di bawah KKM yang telah ditentukan. 
Pendidik memulai dengan menjelaskan tujuan pembelajaran dan kompetensi yang ingin dicapai yaitu anak didik mampu menjelaskan ketentuan Islam tentang zakat dan hikmahnya dan mengidentikasi undang-undang pengelolaan zakat. Dengan tetap melakukan apersepsi dan motivasi pada anak didik khususnya bagi anak yang belum tercapai ketuntasan belajar sebayak 4 orang serta bertanya anak tersebut terkait dengan kesulitan yang dihadapi dalam proses pembelajaran. Berikutnya anak didik diberikan penjelasan terkait dengan materi dalam penggunaan media youtube dan anak didik tetap merasa senang dalam pembahasan zakat dan hikmahnya.

\section{Kesimpulan}

Dari hasil yang didapatkan di atas dapat disimpulkan bahwa pembelajaran dengan media youtube dapat secara optimal pada pembelajaran Fikih siswa kelas X Miftahul Ulum Weding Demak dapat meningkatkan hasil belajar siswa.

\section{Daftar Pustaka}

Arikunto, S. (2017). Penelitian Tindakan Kelas Edisi Revisi. Bumi Aksara.

Baihaqi, A., Mufarroha, A., \& Imani, A. I. T. (2020). Youtube sebagai Media Pembelajaran Pendidikan Agama Islam Efektif di SMK Nurul Yaqin Sampang. EDUSIANA: Jurnal Manajemen dan Pendidikan Islam, 07(01), 74-88.

Carlos Orús, María José Barlés, Daniel Belanche, L. C. (2016). The effects of learnergenerated videos for YouTube on learning outcomes and satisfaction. Computers \& Education, 95(1). https://doi.org/https://doi.org/10.1016/j.compedu.2016.01.007

D Rahmawati S.E, Nugroho, N. M. D. P. (2014). Penerapan Model Pembelajaran Kooperatif Tipe Numbered Head Together Berbasis Eksperimen Untuk Meningkatkan Keterampilan Proses Sains Siswa Smp. UPEJ Unnes Physics Education Journal, 3(1). https://doi.org/10.15294/upej.v3i1.3109

Elianur, C. (2020). Pilihan Media Pembelajaran Daring Oleh Guru PAI di Bengkulu Tengah. Jurnal As-Salam, 4(1), 37-45. https://doi.org/10.37249/as-salam.v4i1.142

Jacub, T. A., Marto, H., \& Darwis, A. (2019). Model Pembelajaran Problem Based Learning Dalam Peningkatan Hasil Belajar Ips (Studi Penelitian Tindakan Kelas Di Smp Negeri 2 Tolitoli). Tolis Ilmiah; Jurnal Penelitian, 1(2), 124-129. https://ojs.umada.ac.id/index.php/Tolis_Ilmiah/article/view/126

Nurgiansah, T. H., Pratama, F. F., \& Iman Nurchotimah, A. S. (2021). Penelitian Tindakan Kelas Dalam Pendidikan Kewarganegaraan. Jurnal Pendidikan PKN (Pancasila dan Kewarganegaraan), 2(1), 10. https://doi.org/10.26418/jppkn.v2i1.41752

Pratiwi, B., \& Hapsari, K. P. (2020). Kemampuan Berpikir Tingkat Tinggi Dalam Pemanfaatan YouTube Sebagai Media Pembelajaran Bahasa Indonesia. 4(2), 282289.

Rasimin, Subqi, I., Eko, H., \& Musyahadah, E. (2012). Media Pembelajaran: Teori dan Aplikasi (U. Hayati (ed.)). Trust Media Publishing.

Salim, H. (2015). Penelitian Tindakan Kelas; Teori dan Aplikasi bagi Mahasiswa, Guru Mata Pelajaran Umum dan PAI di Sekolah. Perdana Publising.

Sari, W., Rifki, A. M., \& Karmila, M. (2020). Pembelajaran Jarak Jauh Pada Masa Darurat Covid 19. Jurnal MAPPESONA, 1, 12. 
Sunardi, M. (2021). Penerapan Metode Pemberian Penjelasan Guna Meningkatkan Prestasi Pembelajaran Pendidikan Agama Islam Materi Meyakini Adanya Hari Akhir pada Siswa Kelas VV Semester I SDN Pule 1 Kecamatan Kandat Kabupaten Kediri Tahun Pelajaran 2017/2018. Jurnal Ilmiah Pengembangan Pendidikan (JIPP), VIII, 69-74.

Susanti, E. T., \& Amelia, M. (2021). Pemanfaatan Youtube Sebagai Media Pembelajaran Matematika Dimasa Pandemi Covid-19. UNINUS Journal Published, 06(02), 1518.

Wijayanto, P. S., Setiawan, W., \& Firmansyah, A. (2020). Meningkatkan hasil belajar siswa melalui media youtube ( podcast ) dengan metode pembelajaran pendidikan jarak jauh pada materi komputer dan jaringan dasar di smkn 3 bandung. Jurnal Guru Komputer, 1(1), 50-62. 